\title{
From Land to the Tiller to Land Liberalisation: The Political Economy of Gujarat's Shifting Land Policy ${ }^{1}$
}

\author{
NIKITA SUD
}

University of Oxford

\begin{abstract}
Land is a metaphor for power, wealth and status. Independent Gujarat's initial mass-development strategy centered on agriculture but the emphasis was on productivity and efficiency rather than land redistribution or social justice. A state apparatus and socio-political set-up dominated by elite landed upper and middle castes and classes ensured this. Primary fieldwork-based research shows that by the mid-1980s, with a growing acceptance of ideas of liberalisation at the national and international level, the elite consensus on land began to shift. This shift must also be placed within local socio-economic developments that had propelled dominant landed groups into agro-industry and small scale industry in the last third of the twentieth century. Gujarat's elite still wanted to control land, but they did not want the state to regulate land use or continue emphasising the diluted but powerful rhetoric of land to the tiller. The rightward shift of all political formations in Gujarat after 1985 and the growing importance of the upper caste-middle class merchant-trader-builder-small businessman dominated Bharatiya Janata Party further facilitated the moves towards a shift in land policy. Continuing changes in Gujarat's land policy are determinedly moving towards the complete liberalisation of land.
\end{abstract}

Land is an important metaphor for power, wealth and status in Gujarat, as indeed it is all over South Asia. One's being a jamin maalik (owner of land) is crucial currency not just in economic transactions involving, say, security for bank loans, but also in social ones of marriage, assertion of standing in ones caste, etc. Obviously, an individual's social, political and economic relationships, crucially

${ }^{1}$ Professor Barbara Harris-White and Dr. Nandini Gooptu read and commented on a draft of this paper, which was presented at the annual conference of the British Association of South Asian Studies, Leeds 2005. I alone am responsible for any remaining inconsistencies.

Contact Address: Queen Elizabeth House, Mansfield Road, Oxford, OX $13_{3}$ TB Email:nikita.sud@qeh.ox.ac.uk

oo26-749X/o6/\$7.5 $0+\$ 0.10$ 
influenced by a state of landedness or landlessness, are not conducted in the sphere of civil society or the market alone. Land in Gujarat cannot be studied without an exploration of the interface of the state ${ }^{2}$ with this important resource. In fact, under the doctrine of 'eminent domain' the state is the ultimate owner of all land. That is, 'the right of the state ... to its ... property is absolute while that of the ... citizen to this property is subject always to the right to take it for public purpose' (Y. V. Chandrachud, quoted in Campaign for People's Control over Natural Resources 2000: 1). The Indian state does not assert its eminence over land in India only at the time of acquisition of land for the building of public roads, railway lines, power projects, etc. The state is the paramount formulator, monitor and facilitator of that crucial conduit of Indian political economy: land policy. This paper investigates the shifting land policy of Gujarat from independence to the present within the context of changing socio-economic and political dynamics. It adopts a regional-local perspective to understand macro issues of state priorities, planning and liberalisation of the economy. In addition, it views land policy and the Gujarat state from an interdisciplinary perspective involving history, politics, sociology and economics.

The evidence used here was collected during D.Phil. fieldwork in Gujarat between June 2004 and January 2005. Research sites were the state capital Gandhinagar, the main cities Ahmedabad, Baroda and Surat, and a remote block of villages in northern Gujarat called Bhiloda. The span of the study however goes beyond the sites of data collection because of the variety of sources being referred to. Interviews were conducted with serving and retired government officials, State and grassroots politicians, members of farmers' organisations affiliated with different political parties, members of civil society organisations, landless agricultural labourers, Gujarati political analysts and journalists. The names of those interviewed have not been revealed in the following pages to maintain confidentiality in what is a politically charged arena of research. Information gained in interviews was corroborated through reading Gujarati and English newspapers published from the national capital Delhi, and from important provincial centres including Ahmedabad, Rajkot

\footnotetext{
${ }^{2}$ In this paper, 'state' refers to the state apparatus-a set of political, administrative and coercive institutions and organisations, more or less well coordinated by an executive authority: the government (Mooij 1996). 'State' (capital 'S') implies the constituent units of the Indian federation. Gujarat is a western Indian State/province.
} 
and Kachchh. Pamphlets brought out by civil society organisations, farmers groups and political parties were a rich source of data, as were government publications such as gazetteers, manuals of land laws and their amendments, and government monitoring reports. Secondary sources inform this study, but mainly for the pre-1980 period. The few secondary sources published after 1980 on the subject cover the impact of the land reforms of the 1960 s and 70 s and not current land policy. ${ }^{3}$ The latter three quarters of this account then, has had to be constructed from primary sources. The following sections trace Gujarat's land policy in three chronological phases. Phase 1, which lasted from independence in 1947 till the mid to late 1970 is formally associated with ideas of land to the tiller, and Phase III from 1989 till to date with those of land liberalisation. In between these two phases, I investigate land policy in the 1980 s, a period of flux in which a final effort was made to pursue ideas of land to the tiller, which then gave way to land liberalisation in a volatile politico-economic context.

\section{Land to the tiller}

While the British government in India adopted practices related to the collection of land revenue, irrigation, the expansion of cultivable area, etc., there was no comprehensive policy related to land ownership and tenancy. Prominent 'peasant' movements in pre-independence Gujarat, say, in Kheda in 1918, were dominated by landed middle caste farmers, especially of the Kanbi-Patidar caste (Hardiman 1981). The Congress, under the Gujarati Patidar leader Vallabhbhai Patel provided leadership in these movements and centred its demands on the waiving of revenue under drought conditions. The needs of landless labour or of the lower caste Baraiya and Patanvadiya tenants or small farmers were not on the agenda of the Gujarati 'peasant' movements. These were not movements that questioned the existing pattern of control over land, and by extension, of social, political and economic dominance. At the same time, as the leading party of India's nationalist movement, the Congress' thinking on land had to attempt to encompass its diverse socio-economic, political and ideological constituencies. Thus, the objectives of economic growth, efficiency and

\footnotetext{
${ }^{3}$ For instance Shah and Sah (2002), Mehta (1995) and Land Reforms Unit (1994).
} 
social justice, in that order of importance, influenced the declaration of an agrarian land programme in the Congress' Karachi and Faizpur sessions of 1931 and $193^{6}$. The agrarian programme stood for land reforms that would reduce rents, abolish the zamindari system and eliminate all intermediaries between the state and cultivators (Shah and Sah 2002: 21). Despite the espousal of socialist principles by some Congress leaders, the nascent land programme of the party that would form the first government of independent India was embedded in the modernist capitalist paradigm of growth and efficiency. Its reformist zeal was most evident in the desire to abolish pre-capitalist modes of agricultural production symbolised by feudal intermediaries or zamindars. Mass social justice or land redistribution were not the primary concern of the Congress leadership.

After independence in 1947 , land reforms were initiated in three stages. During the late 1940 s and in the $195^{\circ}$ s, the agenda was to abolish intermediaries. Stage two aimed at eradicating tenancy, especially sharecropping. The third stage started with the Second Five Year Plan (1956-1961). Its priorities were to regulate the size of holdings that an individual could possess through land ceiling legislation, and then distribute among landless labourers and marginal farmers the surplus land generated. According to the Constitution, agriculture is a state subject. The Union government gives directives and support, with the formulation and implementation of land policy being the responsibility of the Indian provinces. Before 1960, present day Gujarat was divided into three provinces. Mainland Gujarat was part of Bombay province. Peninsular Gujarat became Saurashtra and the north-western desert region of Kachchh came under the administrative control of the Indian union. The 499 politicoadministrative principalities that had formed Saurashtra and Kachchh before independence were merged into the two independent units. The following paragraphs indicate that Gujarat carried out the first stage of reforms, i.e., the abolition of zamindari quite successfully. The second stage granting ownership rights to former tenants was successful in Saurashtra but not in mainland Gujarat. The third stage of land ceiling and redistribution of land to marginalised groups was more or less a failure. The success or failure of different phases of land reforms in Gujarat is not incidental. The popular Twentieth Gentury slogan of khedut ni jamin ${ }^{4}$ or 'land to the tiller' that is associated with

\footnotetext{
${ }^{4}$ See for example R. U. Parikh, Gujarat Minister for Lands and Home (1960), and K. R. Patel, Gujarat Minister for Revenue (in Government of Gujarat 1976).
} 
Gujarati land policy till the early 1980 s masks a complex story. The story involves deep caste and class divisions and a partisan state and polity.

Soon after independence, the administrations of Kachchh, Bombay State and Saurashtra passed several legislations to put into practice the idea of land to the tiller. For instance, as part of the first stage of reforms relating to the abolition of intermediaries, the governments of Saurashtra and Kachchh granted 530 ,ooooo acres ${ }^{5}$ of land vacated by the former princely states to their actual tillers. This was a relatively smooth exercise given that with the merger of the native provinces with the Indian Union, their vast lands had come under the control of the government. Intricate governmental, legislative and bureaucratic arrangements were then required in Saurashtra, which apart from having land belonging to the former principalities, also had some 360,00000 acres of land held by zamindars or intermediary landlords. The latter had been responsible for collecting and paying to the British government the taxes on the land under their jurisdiction. The lands held by them were tilled by tenant farmers who had no security of tenure and little incentive to increase productivity because the zamindars charged rent at will. Zamindari abolition had thus been aimed at protecting the rights of tenants and stimulating agricultural growth. On seeing land allotments to tenants on princely lands in Kachchh and Saurashtra, the zamindars who had not occupied princely lands, started mass evictions of tenants. This prompted the government of Saurashtra to issue a Saurashtra Protection of Tenants of Agricultural Lands Ordinance to stop arbitrary eviction of tenants by landlords in May 1948. Further, the Saurashtra Protection of Tenants (Amendment) Ordinance 1948 was passed to fix rent from tenants to landlords based on an agreement between the intermediary and his tenants and regulated by the government. This rent was not to exceed $1 / 3$ rd of the summer crop and $1 / 4^{\text {th }}$ of the winter crop. The government also appointed a committee of landholders and tenants for settlement of disputes relating to the ejection of tenants from land that had been taken over by the landlords for self-cultivation and for the recovery of rents by landlords from tenants (Patel 1957: 33-34, in Shah 2002: 129; Mehta 1995). Subsequently, despite vocal protests from Saurashtra's landlords, on the recommendation of an Agrarian Reforms Commission appointed by the Government of India in Delhi,

\footnotetext{
${ }^{5} 1$ acre equals $435^{60}$ square feet or 4046.9 square metres.
} 
the government of Saurashtra enacted the Saurashtra Land Reforms Act $195^{1}$ and the Saurashtra Estate Acquisition Act 1952. These acts aimed at abolishing the zamindari system and giving occupancy rights in land to the tillers. In return, the former intermediaries were allowed to retain a portion of their land for personal cultivation. The allocation of this land for self cultivation for the former intermediaries was dependant on the amount of land lost and the quality of land. These Acts were implemented with immediate effect.

To operationalise the various intermediary abolition and secure tenancy legislations, Saurashtra's government instituted an elaborate state revenue and land reform machinery. Its apparatus included block $^{6}$ and district ${ }^{7}$ level officials such as Mamlatdars (Block Revenue Officers), Circle Inspectors and Assistant Collectors (Land Reforms) who worked under the direct supervision of the Chief Minister, the Settlement Commissioner who was also the Chief Secretary of the State, and the Assistant Settlement Commissioner. To indicate the seriousness with which the Saurashtra state took zamindari abolition, a District Collector had ten Mamlatdars and four Assistant Collectors working under him specifically on zamindari abolition and tenancy reform. Moreover, the Assistant Settlement Commissioner who was responsible for the implementation of the reforms, was handpicked by the Chief Minister. The latter himself held a weekly open-house to which both tenants and zamindars brought their grievances. ${ }^{8}$ Besides setting up an effective bureaucratic machinery and administrative practices to implement intermediary abolition and tenancy reforms, the government system in Saurashtra undertook innovative measures when these reforms hit roadblocks. For instance, due to drought in $195^{0}-5^{1}$, only 86 of the $55^{\text {, }}$,oo tenants on former zamindari lands could pay the 6 times revenue assessment which was the agreed sum for purchasing occupancy rights. To solve the problem, the Chief Minister held negotiations with his officials, the Bank of Saurashtra and the Reserve Bank of India to devise a loan scheme which would allow farmers to purchase land. A Land Mortgage Bank was also formed. This was a cooperative venture of farmers, with a membership of 20,00o individuals. The legal titles of the lands of

\footnotetext{
${ }^{6}$ Sub-division of a district; administrative division comprising several villages. Also called Taluka.

${ }^{7}$ Administrative region, comprising several Talukas or blocks of villages.

${ }^{8}$ Interviews with Saurashtra's Assistant Commissioner for Land Reforms 1948-49 and a retired officer of the Saurashtra Administrative Service, Ahmedabad, October 2004 .
} 
tenant-occupants were mortgaged with the Bank till they had paid the full amount required for ownership. The result of all these systematic governmental and legislative efforts between $194^{8}$ and $195^{1-5} 5^{2}$ was that under the first and second phase of reforms in Saurashtra, zamindari was abolished, 55 ,ooo former tenants got occupancy rights over $12,00,000$ acres of land and 33,000 former intermediaries were allotted land for self cultivation amounting to 3 to 1.5 economic holdings of land depending on the amount of land lost and the quality of that land. ${ }^{9}$ After these reforms, both the former tenants and former intermediaries became occupants of the land of the state (Mehta 1995: $103-5)$.

In addition to a committed and intricate state machinery, land reform implementation in Saurashtra was embedded in a conducive socio-political context. The majority of zamindars, who belonged to the Rajput caste, were British loyalists with little association with the ruling Congress party. The beneficiaries of intermediary abolition on the other hand were mainly Kanbi-Patidars, who as has been discussed earlier, had deep links with the Congress. They had based their quest for socio-political mobility on participation in the freedom movement and support to the Congress. Land ownership owing to the reforms also set this important group, which comprises 12 per cent of Gujarat's population, on the path of economic mobility. While state will in implementing land reforms in Saurashtra was unhampered by considerations of riling important political constituencies, the scenario in mainland Gujarat was different. Mainland Gujarat had primarily been part of British India before independence. Most of its land had been administered under the raiyatwari system. That is, revenue was collected by the colonial state directly from the cultivating peasant and not through an intermediary zamindar. However, raiyats or peasant cultivators of Gujarat who controlled large tracts of land, and did employ tenant tillers, came under the tenancy reform legislation of the Bombay Tenancy and Agricultural Lands Act 1948. The Act was aimed at securing the tenure of the tillers who had hitherto been ejected at will, and at assuring reasonable rents. Over time, excess land was also to be passed on to the ownership of the tenant tillers. To implement this Act, an elaborate government machinery was set in place. At

${ }^{9}$ A landholding size that could provide an income of Rupees 1200 at the 1960 price level per annum per family was considered an economic unit and thrice that was adopted for fixing land ceiling while determining land for self cultivation for the former intermediaries (Iyer 2002: 150). 
the block level, 109 Agricultural Lands Tribunal Mamlatdars were appointed for the disposal of applications for ownership rights. At the district level, Tenancy Deputy Collectors with supporting staff were attached to District Collectors, to supervise the work of Agricultural Land Tribunal Mamlatdars. At the provincial level, a Director of Land Reforms and ex-officio Joint Secretary was appointed with the supporting staff of one Deputy Director, one Mamlatdar and others for the implementation of the Act (Government of Gujarat 1976: 11-14). Despite these arrangements, the landowners of mainland Gujarat declared only half the area held under tenancy open to potential ownership by the cultivating lower caste tenants. Even within this group, about $4^{\mathrm{o}}$ per cent of the tenants were denied tenancy rights and made to surrender their land to the landlords, who now claimed to be 'peasant-tillers'. Few tenants could protest because they were also kept away from the hearings of the tribunals that were set up to arbitrate in tenancy and ownership disputes (Shah 2002: 136-37). This is because unlike Saurashtra, caste configurations and political considerations aligned the Brahmin, Baniya and KanbiPatidar bureaucratic and political machinery with the landowners. Local and provincial politicians and bureaucrats did not see it fit to disempower their caste fellows and often themselves by allocating land to their former tenant employees. ${ }^{10}$ Despite adequate state machinery, 'political will' to push through tenancy reforms was found lacking in mainland Gujarat.

After attempting intermediary abolition and tenancy reform, the trigger for undertaking the third stage of land reforms in the 'land to the tiller' phase came from India's Second Five Year Plan that was instituted in $195^{6}$. The Plan indicated the need for redistribution of land by the imposition of ceilings on the amount of land ownership per family. This suggestion was sought to be implemented after present-day Gujarat's three units-Saurashtra, Kachchh and mainland Gujarat had been united as Gujarat State in 1960. Gujarat's first ceiling legislation-the Land Ceiling Act 1960came into force in September 1961 . The Act provided for the fixation of a ceiling on future acquisitions as well as existing holdings. The ceiling limit varied from 19 to 44 acres for perennially irrigated land, $3^{6}$ to $5^{6}$ acres for rice and seasonally irrigated land, and $5^{6}$ to 132 acres for dry lands. Land held in excess of the prescribed ceiling was supposed

\footnotetext{
${ }^{10}$ Interview with a former Commissioner of Land Reforms, October 2004, Ahmedabad.
} 
to be declared as surplus to the local Agricultural Land Tribunals within 90 days of the announcement of the Act. Thereafter, the Land Tribunals were to distribute the declared excess land to priority beneficiaries of the Land Ceiling Act, including Scheduled Caste and Scheduled Tribe landless labour, small land holders, etc (Government of Gujarat 1976: 14). The idea of land ceiling was not welcomed by Gujarat's politically powerful upper and middle caste landed groups. Several ways of escape were devised to avoid ceilings, in collusion with land reform officials and their political bosses. Big landowners resorted to litigation and legal delays-involving the Gujarat Revenue Tribunal and/or the High Court and/or the Collector's office and/or revisions and appeals. They also illegally divided their land in the names of family members. The allottees of surplus ceiling land faced resistance in taking possession of the land and in getting necessary entries made in the village records. A survey conducted by civil service probationers in 1988-91 (Land Reforms Unit 1994) to assess the impact of land reforms all over Gujarat has recorded widespread evasion of Tenancy and Ceiling reforms with the complicity of the state apparatus. For instance, in Visavdar taluka in Junagadh district, the circle officer failed to take possession of surplus declared in 1976 till December 1984. Even in 1984, possession was taken by a Harijan Cooperative Mandali (Scheduled Caste Cooperative Society) only on paper and no entries were made in the mutation register. The original owner continued to till the land, with village officials completely indifferent to the case (Iyer 2002: 162-70). In this scenario, it is easy to believe accounts that declare agricultural land ceiling in Gujarat a complete failure. Even government sources cannot mask this. According to the Statistical Atlas of Gujarat, the area of surplus land acquired till 1981 was 74877 hectares ${ }^{11}$ out of which possession has been taken of 38995 hectares. That is, less than half the land declared surplus has actually been taken over by the government. Further to this, only 20804 hectares have been distributed to $1654^{1}$ beneficiaries (1982-84: 41). From secondary accounts we know that out of these 20804 hectares, many are possessed by beneficiaries on paper.

The fate of land ceiling legislation of the 1960s shows us how the state failed to benefit the landless poor of Gujarat. Shifts in ceiling laws in the 1970s, which will be discussed now, tell another

11 hectare equals 10 ,000 square metres or 2.471 acres. 
politico-economic story. As mentioned earlier, the impetus for the desirability for ceiling legislation came from the Union government, but the actual formulation and implementation of laws depended on the provincial state. Gujarat amended its ceiling legislation 5 times until 1976. The most significant among these Amendment Acts was Act 5 of 1973. While seemingly progressive, on the ground, it provided several more escape hatches in the implementation of land reforms. This was a deliberate move, made under Gujarat's first Patidar Chief Minister, Chimanbhai Patel (1973-74) in response to the demands of Gujarat's landed groups. An important provision of the Act stated that 'the definition of the expression 'to cultivate personally' has been made more restrictive... land is required to be cultivated by the person concerned or a member of his family, i.e., his wife, or a male descendant dependent on him' (Government of Gujarat 1976: 10). In this apparently innocuous statement lies a state-initiated move to undermine the concept of land ceiling. Joint families being the norm in post-independence rural Gujarat, adult sons were not considered separate cultivating units when ceiling legislation was first formulated. If landowners divided land among family members to escape ceiling regulations, they were doing so illegally. This process was widespread before 1973-74, but the Amendment Act made the subversion of ceilings in this manner, legal. In fact, by 'failing' to define 'dependent male descendant', the state left the land owner to decide who was dependant on him. As a result, according to a former Revenue Commissioner, farmers treated infant sons as independent units requiring the ownership of land and easily avoided the imposition of ceilings. ${ }^{12}$ At the same time, the early to mid 1970 s were the height of Prime Minister Indira Gandhi's garibi hatao (remove poverty) 'Socialist' days (Frankel 1978). Chimanbhai Patel's government ostensibly fulfilled its anti-poverty credentials by introducing further provisions in the Land Ceiling Amendment Act of 1973. The Act declared that land is considered personally cultivated only if a person resides at a distance not exceeding 15 kilometres from it. Moreover, 'an absolute ban' was imposed on the purchase of land for agricultural purposes by a non-agriculturist whose annual income from other sources exceeded rupees five thousand (Government of Gujarat 1976: 10). These populist provisions seem to cater to a wide constituency of kheduts (a bland word that covers

${ }^{12}$ Former Revenue Commissioner, interviewed October 2004, Ahmedabad. 
all tillers-landed or landless), but are actually cleverly poised as a barrier for the entry of non-local and non-farming groups into the market for agricultural land. The 'tillers' who stood to benefit from the Amended Ceiling Act of 1973 were not small and landless peasants or agricultural labourers. They were mostly landed Patidars and some farming Brahmin communities such as the Anavils. Their biggest protector and representative was a 'son of the soil' or khedut head of government. Clearly, by 1973 , landed groups were juxtaposing their interests in land against those of Gujarat's traditional merchantbusiness groups - the urban Brahmins and Banias. This was in response to the new socio-economic landscape of the 1970 .

The groups that had benefited from the abolition of zamindari and tenancy reform in the $195^{\circ}$ as and 6os, i.e., mostly Patidars, were gaining further economic strength by the early 70 os due to the thriving white/dairy cooperative revolution and the successful launch of the green revolution. The 1960 s and 70 os also saw a spurt in urbanisation in the State, with the development of newer towns such as Kadi and Unjha. The upper and middle caste beneficiaries of land reforms, capitalist agriculture and cooperative dairying technology began to shift to Gujarat's old urban centres like Ahmedabad and Baroda, as well as the newer ones. Many of the new rural middle class khedut families sent some members (often younger males) to urban centres to build careers in agro-industry, agricultural trade and non-agricultural small-scale industry, while the older generations stayed on with the family land in rural Gujarat. The links-social and economic-between the urban and rural parts of the family were by no means severed. Initial capital for a new business venture came from the family agricultural enterprise and from cooperative banks that well-off farming communities dominated in the 1970s. As a return flow, income from Gujarat's many successful new entrepreneurial ventures was re-invested for further growth and also ploughed back into agriculture. The purchase of agricultural land for industrial or farming purposes, or as an investment was also common. ${ }^{13}$ For tax evasion, industrial or agro-industrial income was almost always shown as agricultural profit, which is not subject to income tax. ${ }^{14}$ In this social and politico-economic context, the Land Ceiling Amendment

${ }^{13}$ For a detailed account of the political and economic activities of the powerful Patidars of rural and semi-urban central Gujarat in this period, see Rutten (1991).

${ }^{14}$ Interviews with a political analyst, a leading Congress party politician and 3 bureaucrats in Ahmedabad and Gandhinagar, July-December 2004. 
Act of 1973 that discouraged non-locals and non-agriculturists from owning agricultural land, is significant. It seemed to come from a state keen to protect tillers from losing their land assets to high bidders from the cities. In actuality though, Gujarat's new urban entrepreneurs from the agricultural middle class did not consider themselves 'non-agriculturists'. Their families very much stuck to their khedut identity. Thus, tillers-turned-entrepreneurs could invest in agricultural land irrespective of income, and their rurally located families bought land unhampered by the residential restriction. Nonkhedut castes such as the traditional merchant-trader Banias on the other hand, might have liked to buy agricultural land to conceal income but were prevented from doing so (at least officially). In one go, the Gujarat state was catering to the rich, powerful, unarticulated and therefore all-encompassing constituency of khedut tillers, and to the need to appear pro-farmer and 'Socialist' in Mrs. Gandhi's garibi hatao agenda. That the Gujarat state, buoyed by an emerging capitalistentrepreneurial class, was far from even a diluted socialism is too obvious to warrant discussion.

To conclude this section, land reforms in Gujarat from independence till the mid-7os were accompanied by the rhetoric of land to the tiller or khedut ni jamin. The khedut tillers who actually benefited from the reforms-their implementation, as in intermediary abolition, as well as their evasion, say in ceilings or tenancy reforms in mainland Gujarat - were the State's rich and middle class, socially and politically powerful middle and upper caste farmers. To the extent of fulfilling their purpose of increasing agricultural production, land reforms were quite successful. However, the reforms did little to empower landless agricultural labour or lower caste small holders of land. The role of the state was central to this policy outcome. While an impressive administrative and political machinery was instituted to implement reforms, this was no guarantee for their success. Politicians and local bureaucrats, deeply entrenched in the dominant caste-class structure of Gujarat, colluded with powerful groups to subvert reforms. By the early 70 , when beneficiaries of land reforms such as the Patidars started to assert themselves in formal State politics, land reform legislation was further amended to suit their interests. At the same time, till the mid-7os, the political economy of Gujarat decisively centred on land. Even the newly urbanising entrepreneurial class anchored its social life on the khedut identity and its economic base on land. This is not the case in Gujarat today. The next section on the 1980s, a period of socio-political and economic flux, is an 
analytical zone of transition for understanding the changes that have seen Gujarat's land policy shift focus from 'land to the tiller' till the 7 os to 'land liberalisation' from the gos onwards.

\section{Nana khedut ni jamin/'Land to the Small Tiller'-The Move Forward and the Snapping Back}

Chief Minister Chimanbhai Patel was removed from power by Prime Minister Indira Gandhi in 1974 after the Navnirman movement that protested corruption in politics (Wood 1975). A period of political flux followed with the State witnessing three ministries and three spells of President's rule till 1980. With so many political changes, no government had time to substantially influence land policy. Interviews with bureaucrats serving in the mid and late 70 indicate that land reforms had lost steam. Land to the tiller rhetoric continued and revenue bureaucrats and district Collectors were urged to allot land to cooperatives of landless labourers from the Scheduled Castes and Scheduled Tribes. However, with little surplus land being declared, little political and bureaucratic will to make large landowners part with land, and political instability, the attempts at redistribution did not go far. ${ }^{15}$ Gujarat saw its first fullterm government in this period of flux in $1980-85$ when the backward caste leader-Madhavsinh Solanki of the Congress, was sworn in as Chief Minsiter. Solanki came to power on the 'KHAM wave'; a political alliance of Kshatriyas (a politico-electoral conglomerate of upper caste Rajputs and numerically strong backward castes such as Kolis), Harijans (Scheduled Castes/former 'untouchables'), Adivasis (Scheduled Tribes) and Muslims. His ministerial Cabinet, a defiant statement against dominant upper and middle castes, did not have a single Patidar minister of senior rank. The 'proletarianisation' of Gujarat's politics needs to be contextualised in a national split in the original Congress between the landed, dominant caste old guard (Congress $(\mathrm{O})$ ) and the group led by Indira Gandhi (Congress (R), subsequently Congress (I)). The latter group depended on Mrs. Gandhi's mass appeal instead of the older strategy of funnelling election majorities for the Congress through local party patrons who commanded the votes of their traditional clients. The split into the

\footnotetext{
${ }^{15}$ Interviews with two retired Indian Administrative Service officers, Gandhinagar, November 2004.
} 
Congress (O) and Congress (R), which happened nationally in 1967 , reflects in the turbulence of Gujarati politics throughout the 1970s. With the decisive victory of Indira Gandhi's Congress in the 1980 general elections, and in Gujarat's assembly elections, the government of the KHAM groups found a five year period in which to attack the dominance of the upper caste bourgeoisie and forward a concrete anti-poverty agenda in Gujarat. Not surprisingly, in the KHAM years, attempts were also made to influence land policy.

One of the most striking land-related initiatives of Madhavsinh Solanki's government was to attempt a reversal of the provisions of the Ceiling Amendment Act of 1973 that allowed major sons to be independent holders of land. The government re-opened cases against large landholders who had subverted ceiling law by dividing land among family members. The number of such cases that had been pushed under the carpet because of the coming into force of the 1973 Amendment was an astounding 25,00o! The government was well aware that locally entrenched bureaucrats would not willingly support the new land initiative. A solution came with backward caste politician Jinabhai Darji-the architect of KHAM—suggesting that redistribution of the freed land to Dalits would go ahead through village Congress workers, even if some bureaucrats did not cooperate. Quite expectedly, the new government's enthusiastic drive to redistribute land invited protest. Politically powerful individuals such as Chimanbhai Patel and Keshubhai Patel (who went on to become Gujarat's first BJP Chief Minister in 1995) filed writ petitions in the High Court to stall the perusal of the 25, 0oo cases. In addition, a conglomerate of 13 upper/middle caste-upper/middle class dominated organisations petitioned the High Court to halt the Solanki government's new land initiative. Among these powerful bodies were the Gujarat Chamber of Commerce and Industry, the Gujarat Chamber of Agriculture and the Khedut Samaj (Farmers Society). The agro-industrial elite of Gujarat was revolting against the KHAM government. District Collectors who usually belong to the elite Indian Administrative Service, began to report that if the cases were not given up, 'class war' would break out in Gujarat. Under tremendous strain from various sides, by 1983 the government had withdrawn all cases against the evaders of land ceiling. ${ }^{16}$

${ }^{16}$ Soyantar (1994); and interview with former Additional Chief SecretaryRevenue, October 2004, Ahmedabad. 
The Solanki government was facing 'elite revolts'17 in land policy, as well as to its other actions affecting the socio-economic and political spheres. 1981 had seen anti-Dalit riots when the government had announced reservations for Scheduled Castes in educational institutions like medical schools. Given the hostile political climate, the government made no further open attempts at challenging, on a large scale, upper and middle caste dominance in land. At the same time, it faced pressure from Delhi to seriously implement the Twenty Point Programme, with poverty alleviation as a major goal. Unwilling to openly rock Gujarat's land structure, but searching for avenues to appear to be implementing its pro-poor pro-backward groups promises, the Solanki government set up a Commission to review Gujarat's land policy. Jinabhai Darji, the Chairman of the Twenty Point Programme, headed the Commission. By 1984, the Jinabhai Darji Commission had produced its recommendations. Chief among these was an expansion of the scope of the Tenancy Act to include all non-tiller landowners. The latter were to be made to surrender land to their cultivating tenants. Darji suggested that if land was not being cultivated by family labour, it must be retracted for redistribution. He also emphasised that a rule compelling all land owner-tillers to be residing within 8 kilometres of their land must be strictly enforced. These were radical ideas for a State where the agroindustrial elite was increasingly investing in large tracts of agricultural land well beyond the 8 kilometre residence limits. In a political climate of 'caste war', the Jinabhai Darji Committee Report on Land Policy was never tabled. Even an avowedly progressive, pro-poor government failed to shake the entrenched dominant interests in Gujarat's land. Its attempts to redistribute land to landless tillers were made to fail.

While the Solanki government's attempts at large-scale changes in land policy did not succeed, some stray initiatives to enable the landless poor to access land did materialise. Significantly, as it was being realised that fundamental changes in the structure of land ownership might be politically impossible, the focus of land policy began to change towards schemes that periodically leased government land to the poor. For instance, as part of the Twenty Point Programme, Jinabhai Darji tried to promote a scheme to allot land on yearly and three yearly leases to cooperatives of Dalit and Adivasi landless labour. This land was to

${ }^{17}$ From Corbridge and Harriss (2000). 
come from the government's kitty of surplus land, especially that which had been freed after water from non-perennial water sources had dried up. It was estimated that cultivation of fertile pond and river-beds for 9 months in the year would benefit 300 ,ooo landless labourers. The pilot project of this scheme was undertaken in the Hathmati river basin in North Gujarat. When the Hathmati river had been dammed in 1962,6 villages were submerged completely while 14 villages were submerged partly. The government had acquired 10,000 acres of land

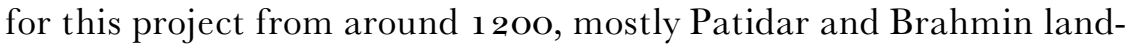
holders. All the landowners were given cash compensation and land and rehabilitated elsewhere. The government also made provision for agricultural use of the land of the state-owned Hathmati reservoir after the water from it had been released into irrigation channels. It formulated rules through a Government Resolution passed in 1962 according to which the original owners were to get a maximum of three acres of land from the Hathmati basin on lease. This was conditional on the owner (a) tilling the land himself, (b) earning his livelihood from agriculture, (c) living within a radius of 15 kilometres of the dam, (d) not already possessing more than 16 acres of land. The remaining land was to be distributed on lease to the landless labourers and marginal farmers of the area. This would aid those who had lost employment after the land around the Hathmati had been acquired for the reservoir by the government, and had not been compensated in any other way (Adhvaryu 1982). The government resolution of 1962 was not implemented immediately, nor was it made public. Government officers in Bhiloda and Sabarkantha towns in the Hathmati region seemed unaware of its existence, and went on colluding with local landed interests to maintain status quo in land. That is, the local bureaucratic machinery allowed the original landowners to continue tilling the reservoir land in the proportion they used to own before the land was acquired by the government. As a result, the landless labour that had lost employment on upper castes' fields when the Hathmati Dam was built received no compensation in the form of reservoir land leased from the government, or other alternative employment. In this context, a Gandhian upper caste schoolteacher based in Bhiloda town in the Hathmati region, with access to Jinabhai Darji and the revenue bureaucracy in Gandhinagar chanced upon the 1962 Government Resolution in the late $197 \mathrm{Os}$. He used it to organise the local landless Dalits and Adivasis and started an agitation to reclaim the right of the landless of Bhiloda to access Hathmati reservoir land. The movement of the organisation they formed-the Shramjivi Samaj-would not 
have received much official assistance in the 7os. But in the KHAM years, the Shramjivi Samaj received the patronage of no other than Jinabhai Darji (Adhvaryu 1982).

In June 1981, as Chairman of the Twenty Point Programme Committee, Jinabhai Darji called a meeting of the workers of the Shramjivi Samaj and government officials of the Revenue and Cooperation departments. He made the officials allocate $175^{\circ}$ acres of land to cooperatives of landless Dalits and Adivasis that had been formed by the Shramjivi Samaj. Local officials who would normally have refused to assist Shramjivi Samaj cooperatives in Bhiloda were compelled to do so during the rule of what they reluctantly termed tamaari sarkar ('your, i.e., the lower castes' government'). ${ }^{18}$ It should be added that the former landowners of the Hathmati land were not passive during the Shramjivi Samaj movement. During each sowing season while the movement was building up, they raised issues of 'law and order' with the government and registered false police cases against the landless Dalits and Adivasis. Interestingly, one part of the government system-the local coercive apparatuswas being used here to contest an initiative supported by another part of government-the top political executive. The leadership of the landowners of the Hathmati area was assumed by ex-Congress Member of Legislative Assembly from 1962, Ganpatlal Trivedi and the then president of the Sabarkantha district Janata Party. Other local high caste Congress (I) leaders who did not fit into or agree with the KHAM framework also supported the former landowners. They formed a Save Land Association and filed writ petitions in the Gujarat High Court contesting the grant of land to the Shramjivi Samaj. When these were dismissed, they put further political pressure on the Gujarat government. On October 51981 , they converged on the State capital Gandhinagar in hundreds to meet the Chief Minister and Irrigation Minister. Succumbing to sustained pressure from the landed groups of Bhiloda and Gujarati upper-middle castes in general, the government raised the land ceiling for individual cultivation in the Hathmati basin for former landowners from three to six acres for each member of the landlords' families. Yet again, the KHAM government had been forced to backtrack on land policy decisions. However, it also managed to keep repeating the leases of the DalitAdivasi cooperatives. They cultivate Hathmati basin land till to date.

${ }^{18}$ Interview with the Secretary, Shramjivi Samaj, in Bhiloda, September 2004. 
Despite this one-off success, the Bhiloda experiment could not be reproduced across Gujarat.

With the revoking of the 25, 000 cases against the violators of land ceilings, the shelving of the Jinabhai Darji Committee report that recommended structural changes in land holding, and the preventing of the Bhiloda experiment from being reproduced, it becomes quite clear that a government that set out to substantially change Gujarat's land policy when it came to power on a pro-poor, pro-landless mandate in 1980 had been forced to change course by 1983 by the conservative politico-economic context of Gujarat. A progressive version of 'land to the tiller', i.e., 'land to the small tiller' or nana (small) khedut ni jamin had been proposed and withdrawn in three flux filled years.

\section{Backtracking on khedut ni jamin; Moving Towards the Liberalisation of Land}

In its final years, the Solanki government was besieged by attacks from the upper castes on its policy of reservation for Scheduled and Backward castes in public employment and education. It is estimated that 210 people were killed in the pan-Gujarat anti-reservation violence of 1985 (Nandy et al. 1995: 121-2). Despite (or perhaps because of) re-election on the KHAM agenda in March 1985, the attacks against Solanki's leadership and anti-lower caste and antiMuslim ${ }^{19}$ violence all over the State did not abate. Finally, the Chief Minister was forced to resign in July 1985 . Even before Solanki's formal resignation, observers of Gujarati politics comment that the KHAM government had begun to backtrack on its social commitment. In the sphere of land policy, there was certainly a freeze on any new initiatives that would suggest that this was a government that had once been committed to ideals of land for the poor. In fact, individuals like Jinabhai Darji were sidelined and Solanki increasingly began to subscribe to an ostensibly conflict-free trickle down approach to the State's development. A political analyst has termed this as the 'elitisation' of Madhavsinh Solanki. ${ }^{20}$ In the mid-8os, the Chief Minister concentrated his energies, and those of his administration, on the promotion of the interests of Gujarat's disgruntled trader-business

${ }^{19}$ For how Muslims were brought into the anti-reservation violence of 1985 see Shani (2001) and Yagnik (2002).

${ }^{20}$ Interviewed in Ahmedabad, July 2004. 
groups. Gujarat has encouraged industry for several centuries now, with the once-flourishing textile industry being a case in point. However, a clear demarcation has been kept between land for industry and land for agriculture. Even Chimanbhai Patel enacted a legislation disallowing a non-agriculturist with an income of more than 5 ooo rupees from buying agricultural land-the idea being to not let Gujarat's agricultural land be taken over by industry. Strict rules were put in place to convert agricultural land to non-agricultural statuswith much bribing and red tape being involved to make the shift from 'A' to 'NA'. This changed to some extent in the latter Solanki years, with the Chief Minister himself sanctioning large tracts of fertile stateowned to industrial houses at very cheap rates. ${ }^{21}$ This was not done under any formal land policy shifts, though. It was an arbitrary process. The following decade would see moves to formalise the convertibility of agricultural to non-agricultural land within a larger policy of land liberalisation. This formal shift did not happen till 1995. However, with the political focus beginning to shift away from 'land to the tiller' from the mid-8os and a growing acceptance for a more eclectic use of the state's land, the move towards land liberalisation had begun.

There is a socio-economic context to the growing acceptance of eventual land liberalisation in Gujarat. The emerging entrepreneurial groups of the 1960 s and 70 s who were then beginning to make the transition from agriculture to agro-industry, and plastics, chemicals, dye, pharmaceutical industry, etc., and rural to urban living, had continued to base their social identity on their agriculturist roots and on their agricultural land holdings. However, the 25.7 per cent urbanisation rate in 1961 had increased to 34.5 per cent by 1991 . This shows that by the 1980 , the nouveau riche entrepreneurial groups (as opposed to the traditional Brahmin-Bania-Khoja mercantile groups) had moved more decidedly and in greater numbers to the cities and were ready to make the transition to full-time non-agricultural urban occupations. ${ }^{22}$ They still wanted to control land, but this did not necessarily have to be agricultural land. They wanted the choice to be able to convert their agricultural land for a non-agricultural purpose,

${ }^{21}$ Interview with a leading politician, Gandhinagar, August 2004.

${ }^{22}$ The percentage of urban population was 25.77 per cent in $1961,28.08$ per cent in $1971,31.10$ in $1981,34.49$ per cent in 1991 and 37.67 per cent in 2001 (excludes Kachchh, Jamnagar and Rajkot where census could not be conducted due to the earthquake), Directorate of Census Operations 2001. 
or purchase land for agricultural or non-agricultural purposes anywhere in the State. Thus, while the Patidar dominated Khedut Samaj had petitioned Chief Minister Chimanbhai Patel to not allow industrialists (then mostly Brahmins and Banias) to purchase agricultural land in 1972-73, the same 'khedut' organisation petitioned Madhavsinh Solanki and his successor Amarsinh Chaudhary to allow the free sale and purchase of agricultural land for any purpose in any part of Gujarat in 1986-87. Gujarat's changing economy and its changing society and polity were behind these demands for shifts in land policy. ${ }^{23}$ A besieged Congress party, which by 1985 wanted to survive in government by any means possible (Kohli 1990), kept giving in to the demands of powerful farmers' and business organisations. This reflects in its continuous backtracking on the fundamentals of Gujarat's land policy.

Solanki's successor Amarsinh Chaudhary of the Congress, was Gujarat's first Adivasi Chief Minister. The KHAM agenda had certainly boosted his political career. However, in the political scenario of the mid and late 80 , Chaudhary did little to align his general development policy with Gujarat's poor. One of his significant moves in the field of land policy was to change the hitherto sacrosanct rule, enshrined in Section 2(6) of the Bombay Tenancy and Agricultural Land Rules 1956, disallowing any purchase or sale of agricultural land beyond an 8 kilometre residential limit. This, more than any other land-related ruling, was most associated with the idea of land to the tiller. To keep land in the hands of actual tillers or at least their direct supervisors, rather than well-off people residing in distant places, government after government had upheld the '8 kilometre rule' in Gujarat. ${ }^{24}$ However, under pressure from rich farmers' organisations, builders, industrial lobbies and opposition politicians from the predominantly upper and middle caste BJP and Janata Dal, Amarsinh Chaudhary used the drought years of $1987-89$ to change the 8-kilometre rule for drought-affected areas. He couched this in pro-poor farmer rhetoric, positioning the change as being beneficial for poor, drought-hit farmers who would now have easy liquidity with the option of selling their land to anyone and buying new land in

${ }^{23}$ Based on interviews with the Vice-President, Gujarat Khedut Sangharsh Samiti, November 2004, Ahmedabad; and an ex-Congressman and Convenor, Gujarat Khedut Sangharsh Samiti, October 2004, Ahmedabad.

${ }^{24}$ C. M. Joshi (IAS retd.) 'Tinkering With Gujarat Land Laws', The Times of India, Ahmedabad Edition, 10.9.88. 
better irrigated areas! The state Revenue Minister announced the shift in 8 kilometre regulations in the State Legislative Assembly as an 'improvement' and 'concessions' in Gujarat's land laws (July 1988, in Vyas et al. 1989). The 'concessions' that were being made were quite clearly to elite social and political formations, which now accommodated several ex-Congress politicians who had left the party in the KHAM years.

There was little protest to the precursor of Gujarat's land liberalisation drive. Newspapers reported that Madhavsinh Solanki and Jinabhai Darji shot off angry letters to Prime Minister Rajiv Gandhi calling the Chaudhary government's measure 'anti-people'. However, these leaders were completely sidelined in the Congress party and their protests were largely ignored. ${ }^{25}$ Commentators expressed surprise at the studied silence maintained by the backward caste, Scheduled Caste and Scheduled Tribe Members of Legislative Assembly (MLAs) who made up the majority of the Congress contingent in the Gujarat legislature. The caste kin and electoral constituencies of these political leaders were set to suffer the most from the change in land law. However an Assembly that was dominated by the KHAM groups only meant that one (upper and middle caste) elite had been replaced by another. The KHAM elite did not protest the change in land law. ${ }^{26}$ Some civil society groups did remonstrate against the new rule. One organisation termed the change a 'loosening' of the land laws, which would now enable rich farmers to take advantage of the desperate condition of poor droughtaffected farmers and buy off their land cheaply. Instead of buying land in other parts of Gujarat, the newly landless farmers would enter the growing pool of landless labour. This pool would help depress the agricultural labour wage and add to the corpus of cheap unskilled labour for the State's burgeoning, mostly unregulated industry (Vyas et al. 1989). But such protests were in the minority, with all major 'khedut' or farmers' organisations supporting Gujarat's changing land laws. This of course gave legitimacy to the move since these 'khedut' organisations claimed to be speaking for all farmers, while actually pushing the agendas of the better off ones with large pieces of land. This reiterates my point about the elite nature of the idea of 'tillers' in

${ }^{25}$ Jansatta 'Jamin dharama Chaudhary sarkarna sudhara Gujarat Congima vikhvadna vad chade che', Jansatta, Ahmedabad Edition (in Gujarati), 24.7.88.

${ }^{26}$ Harish Khare 'Land law in Gujarat. Poor Farmers Milched Again', The Times of India, Ahmedabad Edition, 23.8.88. 
much Gujarati political-social discourse. It also tells us that by 1988 , Gujarat was well on its way to the liberalisation of land.

\section{The Tumultuous gos: Setting the Socio-political and Economic Context for the Liberalisation of Land}

The political and electoral logic of KHAM was destroyed by repeated caste violence in the 1980 s. In the 90 s, the polity of Gujarat underwent tumult while political alignments got re-formulated and tested once again. The decade saw the State witness a spell of President's rule in September-October 1996 and 8 Chief Ministers from different political parties and party coalitions including the BJP-Janata Party that was dominated by landed farmers (1990), Janata Party-Congress and then just the Congress into which the Janata Party had been merged (1990-94), the BJP (1995-96) that has traditionally been supported by the urban trader-business class but has gradually broadened its constituency, the Rashtriya Janata Party or RJP that was an offshoot of the BJP (1996-98) and finally from 1998 till the present, the BJP. Several factors make this period of political tumult distinct in the context of the focus of this paper. First, despite frequent changes in the political executive and legislative composition of the state, the move towards the liberalisation of land has been steady. Often, the party in power has carried forward the land policies of its predecessor. For instance, the following section will show that while the Congress government attempted to abolish the 8 kilometre rule in 1994 and failed to muster enough political support to do so, the very next year the BJP government passed the relevant bill in the State Legislative Assembly. Second, along with a continuity in policies despite formal political changes, one also sees a continuity in the political actors in government in this period. This is because the 1990 s have seen much party hopping by politicians, making each party resemble the other in terms of policies as well as people. For instance, a former Industries Minister of Gujarat, who was also Chief Minister for a brief period in 1997, has been a member of the BJP, the RJP as well as the Congress between 1990 and 2002. Being a prominent industrialist and former Chair of the Gujarat Chamber of Commerce and Industry, he is completely in favour of the on-going land liberalisation. According to him, it is not surprising that different parties in Gujarat have espoused the same land policies, or that political actors have changed party affiliations easily simply because 
'ideology has nothing to do with it'. ${ }^{27}$ With the destruction of the logic of KHAM and the gradual but definite withdrawal of schemes that, say, provided wasteland to the poor, Gujarat's polity as well as political economy have seen a gradual rightward shift in the 1990s. Scholars have called the Gujarati political economy conservative even with reference to the $5^{\mathrm{O}}$ and $60 \mathrm{~s}$ (Mukta 2002). However, the rightward shift in all parties, including the Congress in the gos is quite striking. While earlier decades had centrist alternatives such as Indira Gandhi's Congress, the gos have none. The general rightward shift in Gujarat's polity and political economy provides the ideal setting for a largely uncontested liberalisation of land in the province.

In the backdrop of the political tumult and rightward shift in Gujarat's polity, an important feature has been the steady strengthening of the Hindu nationalist BJP and the downward spiral of the Congress party. The Congress in Gujarat today is neither associated with its older Adivasi tribal, lower caste and Muslim constituency, nor has it been able to find favour with the Hindu upper caste-middle class. As it tries to straddle different political constituencies, it is difficult to associate it with any particular political and economic agenda or ideology. In this backdrop, the BJP and the Hindu nationalist movement that supported it have been on the ascendant all over India and in Gujarat from the mid-1980s. In Gujarat, the movement has found a ready political constituency in the upper and middle caste, upper and middle class population that had got disenchanted from the Congress in the 7os and especially the 8os owing to its ostensibly pro-poor, pro-lower caste and developmental leanings. In this political climate, the Hindutva movement was able to strengthen its youth groups, women's organisations, and general socio-political network. This reflected in its ability to gather mass support for several Hindu nationalist mobilisational programmes that took place in Gujarat in the latter half of the 1980 s and early 1990 s. Some of these included the Ram-Janki Dharma Yatra (the holy procession of Lord Ram and his consort) in 1987 , Ramshila Pujan (the sacred consecration of bricks for the Ram temple in Ayodhya) in 1989, Ramjyoti Yatra (chariot procession to commemorate the light of Lord Ram) and Vijayadashami Vijay Yatra (Lord Ram's victory day procession) of 1990 and national BJP leader L. K. Advani's Rath Yatra or chariot procession from Somnath in peninsular Gujarat to Ayodhya, the alleged birthplace

${ }^{27}$ Politician, interviewed in Ahmedabad, October 2004. 
of Lord Ram in North India, also in 1990 (Nandy et al. 1995). Deliberately orchestrated violence against Muslims and Christians often accompanied these shows of Hindu unity and strength. ${ }^{28}$

Two feats were being attempted by the Hindu nationalist movement through its socio-political programmes of the 1980 s and 9os: one, the projection of the Hindu nationalist movement and the $\mathrm{BJP}$ as viable political alternatives to the crumbling Congress, and two, the formation of an electoral and socio-political coalition to counter KHAM - the coalition of Hindus. Lower castes and Adivasis were included in this coalition, and have often joined to attain social mobility within the dominant Hindu social order. Interestingly, while the Hindu nationalists in Gujarat, both in the late 8os-early 9os and today, claim to speak for the united culture, society and polity of all Gujarati 'Hindus' irrespective of caste, they are quite silent on economic issues. Very occasionally, these may be brought up by say, the farmers' wing of the Hindu nationalist movement - the Bharatiya Kisan Sangh (2003), or in the pro-industry publications of the Vishwa Samvad Kendra which is a documentation centre of the Hindu Right. Thus, a book from the latter that showcases the 'uniqueness of Gujarat' (Gujarat etle Gujarat aj) (Mehta 2002), comments on the need for corporatising agriculture to make it commercially viable, encouraging agro-industries, and making the water of the Narmada dam reach remote parts of Gujarat to facilitate irrigation. However, there is no mention of landless labour, issues of minimum wages for agricultural workers, or of facilities for marginal farmers who cannot afford irrigation pumps to lift canal water (Jadav and Marvia 2002: 26-8). The politico-economic slant of the Hindu nationalist movement and of its various constituent organisations is quite openly pro-rich.

Contemporary Gujarat is a site of complex socio-political formations exhorting simplistic, frozen ethnic identities of Hinduness and Gujaratiness; and it is a canvas for a blind charge towards commercialisation and industry-driven economic 'progress'. There are few rules except the increasing stepping back of the state, and the aggressively articulated belief that industrialisation and globalisation will increase the asmita or pride and sense of identity of aapnu Gujarat aagvu Gujarat (our Gujarat, unique Gujarat) (see Government of Gujarat 2003). The rolling back of the state and the formal welcoming of economic liberalisation all over India from 1991 strengthens and

${ }^{28}$ Hindustan Times 'Four killed in fresh Gujarat violence', Hindustan Times, Delhi Edition. 1 1.4.87. 
encourages Gujarat's strides in this direction. ${ }^{29}$ For instance, in its neighbouring Maharashtra, land ceiling measures enshrined in Section 47 of the Land Ceiling Act of 1961 have been reversed from 1993 for specific agricultural purposes. Individuals, cooperative groups or private companies can lease tracts of land for up to 35 years, over ceiling limits, if they can prove that the land will be used for horticulture or agro-processing (Vijapurkar 1993). This was possible before 1993 too, but only after obtaining the District Collector's permission and formally converting the land into 'non-agricultural' usage. But with the adoption of the New Economic Policy, States like Maharashtra and Gujarat have used Delhi's support as a key for withdrawing what many elites in these states consider stifling state controls. Of course, some other elites who are hit by these new liberalisation measures may protest, but even then the larger climate is used as an excuse to suggest that the liberalising State government is helpless. If it does not keep up with liberalisation measures, it will be left behind by other States. Gujarat has used this context to get New Delhi's nod for several land-related projects, including the changing of land use of a wildlife sanctuary in Kachchh in 1995 to facilitate the building of a cement plant and jetty by the sea. ${ }^{30}$ In this freewheeling politico-economic environment, it should come as no surprise that all ideas of 'land to the tiller' have been rolled back. The liberalisation of land is the unquestioned order of the day in contemporary Gujarat.

\section{Land Policy in the 199os: Unquestioned Liberalisation}

The 1990 s saw a determined push by all Gujarati political parties towards the liberalisation of land. By the end of the decade, land policy in Gujarat had undergone a significant about turn from where it had begun after independence-in ideas of land to the tiller. Keeping in mind the context of political tumult, a rightward shift in the policy stances of all political parties, and nationally changing ideas related to agricultural land holding and liberalisation, which has been set out

\footnotetext{
${ }^{29}$ For an overview of liberalisation in India see Rothermund (1996), Jenkins (1999) and Nayar (2001).

${ }^{30}$ Interview with the lawyer who fought this case for environmental and civil groups in the High Court, against the Gujarat government and Sanghi Cement Limited, December 2004, Ahmedabad; Gujarat Samachar, 'Narayan Sarovarni jamin mukt karvana prashne upapoh', Gujarat Samachar, Ahmedabad, 14.7.94 (in Gujarati).
} 
above, I now chronologically trace the provisions of Gujarat's push towards a less regulated, more market-friendly land policy.

As a continuation of the change in the 8 kilometre law regulating the sale and purchase of land for drought-hit areas that was introduced in 1988, the Janata Party-BJP and the Janata PartyCongress governments (1990-1994) tried to universalise the lifting of the rule across Gujarat. However, the 'land to the tiller' script was still powerful enough to dissuade the parties from pushing through the change fearing a political backlash. At the same time, the drive for making this change in the law and allowing free sale and purchase of land anywhere in Gujarat was strong. It came from rich farmers, especially in the post-Narmada Dam context. ${ }^{31}$ Politically and administratively well connected agriculturists and land speculators knew that they could use the system to get advance information and project maps showing the outlay of the new Narmada irrigation canals. With the formal lifting of the 8 kilometre rule, farmers intended to use their political connections to buy land cheap before the canals were built and later sell it at high rates or use the new water source for growing lucrative cash crops. ${ }^{32}$ In addition, agro-industrialists, industrial entrepreneurs and traders were keen to invest in agricultural land to conceal their income and evade tax. The lifting of the 8 kilometre rule would make their task of purchasing land easier. ${ }^{33}$ The push to lift the 8 kilometre rule also came from builders who envisaged buying agricultural land on the periphery of several Gujarati towns and cities and building commercial and residential complexes on it. Most importantly, from the 1990s, the state's land policies are no longer just catering to large landed farmers, local industrialists and small scale entrepreneurs. Today, land liberalisation is considered a prerequisite for attracting foreign and national investment to a 'globalising Gujarat' (Government of Gujarat 2003). The exchange of land unhindered by residential restrictions is demanded by international corporate firms, national investors, new software and IT industries, and large enterprises that are setting up special economic zones and require vast amounts of land. The agency facilitating the acquisition of land by the actors of the

\footnotetext{
${ }^{31}$ For more on the Narmada Dam project, see Alvares and Billorey (1988) and Baviskar (2004).

${ }^{32}$ Interview with a retired Indian Audit and Account Service officer, who served on the Board of Sardar Sarovar Narmada Nigam Limited, Ahmedabad, November 2004.

${ }^{33}$ Govindbhai Jadhav, 'Game tyan jamin kharidvanu vidheyak navo samantshahi varg ubho karshe',Jansatta, Ahmedabad, 6.4.95 (in Gujarati).
} 
new liberalised economy is the Gujarat government. In this context of a clamour for the unregulated sale and purchase of land, finally, when Gujarat's first BJP government came to power in March 1995, it scrapped the 8 kilometre rule in its very first Legislative Assembly session by successfully proposing a Tenancy Bill amending the Bombay Tenancy and Agricultural Lands Act 1956. Some feeble protests were heard from the Congress, which staged a walk-out from the Assembly when the proposed amendment was being discussed. However, the BJP was in majority and the Amendment Bill was passed without a problem. Gujarati newspapers reported that many members of the Congress, especially those that had joined the party after the KHAM years were very much in favour of the new Bill. ${ }^{34}$ Moreover, unlike 1988 when some social organisations had protested against the change in the 8 kilometre rule for drought-affected areas, in 1995, there was hardly any dissent. As several members of prominent civil society organisations told this author, the momentum for protesting against land liberalisation policies was just not there in mid-gos Gujarat. ${ }^{35}$

While moves towards the liberalisation of land have been on in full swing, politicians have not forgotten their electoral constituencies that often comprise the landless poor. Periodically, schemes are announced for providing government waste land to people living below the poverty line. ${ }^{36}$ For instance, in 1994 a Congress government (with which the pro rich-farmer Janata Party had been merged) announced that 2600,00o rural poor below the poverty line would get two hectares of government waste land for agriculture. District Collectors and District Development Officers were ordered to begin implementing this scheme. ${ }^{37}$ However, members of civil society organisations working with the landless called this announcement a 'political gimmick'. They pointed out that this wasteland to the poor scheme was not

${ }^{34}$ Express News Service, 'GLP divided over Bill to amend Land Act', Indian Express, Ahmedabad Edition, 28.3.95.

${ }^{35}$ Interviews with the Secretary, Gujarat Khet Vikas Parishad, Ahmedabad July 2004; and the Secretary, Shramjivi Samaj, Bhiloda, September 2004.

${ }^{36}$ Being Below Poverty Line (BPL) is generally the foremost criteria for eligibility for anti-poverty programmes in India. A survey to assess BPL families in each Indian province is conducted at the beginning of a Five Year Plan period. In this assessment, measures such as per capita expenditure and asset ownership are used. For Gujarat, the per capita monthly expenditure limit for being considered BPL for the Ninth Plan (1997-2002) was Rupees 254* (Government of India 1997).

$* £ 1=$ approximately, Indian Rupees 80

37 Express News Service '26 lakh rural poor to get agricultural land', Indian Express, Ahmedabad Edition, 7.7.94. 
new. It had been in operation for decades, with Scheduled Castes, Scheduled Tribes and Backward Castes being eligible to receive cultivable wasteland. However, the government should be well aware that grassroots bureaucracy and politicians belong to the same castes as local vested interests and ensure that such schemes are never implemented. Officials may transfer wasteland to village pasture so that it cannot be allotted to a landless person. Or, they may allow an upper caste to illegally cultivate this land. Local officials report to district-level bureaucrats such as Collectors. By fudging figures, they ensure that a Collector or District Development Officer never has a clear picture of how much wasteland is actually available in a village for allotment to the poor. Governments merely indulge in political rhetoric by making land to the poor announcements. ${ }^{38}$

While land for the poor schemes have been announced and remained unimplemented, the use of land to facilitate Gujarat's industrialisation drive has powered ahead. A former Revenue Secretary in the Government of Gujarat confirmed that all landrelated departments have instructions to do all they can to ensure that industrial projects-Indian and international-access land of their choosing without bureaucratic delay. This does not mean that the petty bureaucrats and politicians who block land to the poor schemes do not attempt to interfere in land transfers to industry in their localities or demand bribes. The difference between the two situations is that top officials and politicians, often from the Chief Minister's Office, intervene to ensure land deals are conducted smoothly in the latter situation. In addition, senior land and industry department bureaucrats in the State capital recommend that interested industrial parties employ retired land officials such as Mamlatdars to get around the intricacies of land acquisition for industry. ${ }^{39}$ In short, today, permission for converting agricultural land to a non-agricultural purpose or for circumventing land ceiling laws is given by senior executives in the Gujarati state apparatus, with the groundwork being done by former employees at the level of local government who are well versed in how the state works. An example of hurried land acquisition for industry pertains to the purchase of 1400 acres of agricultural land

${ }^{38}$ Javed Ameer, 'A political gimmick', The Times of India, Ahmedabad Edition, 16.7.94; and interview with a social activist who has worked on rural land rights, Ahmedabad, November 2004.

${ }^{39}$ Interview with a former Revenue Secretary of the Government of Gujarat, Gandhinagar, September 2004. 
for Reliance Petroleum at Meghpar and Padana villages of Jamnagar district in 1993. The fertile agricultural land was given to Reliance at the rate of Rupees 2 and Rupees 3 or £o.o3 per square metre, with the state playing the role of facilitator. ${ }^{40}$

The Congress has been out of power in Gujarat from 1995. None of its succeeding governments have targeted the poor or landless as core electoral constituencies. The BJP, for instance, appeals to the Hinduness and Gujaratiness of a Scheduled Caste youth, not his or her unemployed or exploited status. At the same time, the BJP cannot ignore the electoral consequences of repeatedly introducing pro-industry policies that go against the poor and landless. One is led to wonder then, how has government after government in Gujarat powered ahead with the liberalisation agenda? Some of the reasons for this are (a) there is a lack of information about the rapidly changing land-related measures. The latter are often initiated through Government Resolutions and internal orders that are not easily accessible. Thus, even though land liberalisation measures have been gaining momentum, some of the province's leading social scientists and journalists that I interviewed were not aware of the main provisions of changing land laws. By the time the effects of changes in land policies reach Gujarat's poor and landless, the processes that put them in motion are irrevocable. (b) One of the crucial fora in which political opposition to liberalisation of land may be expressed-the State Legislative Assembly_is less and less a space for doing so. In the 1970 and 80 , while legislators met in the assembly for around 60 days in a year, the number had gone down to around 35 in the 1990 . The spiral has continued in this decade. For instance, in August 2004, Chief Minister Modi of the BJP called a day's special session of the Legislative Assembly to condole the death of a political leader. He then decreed that the requirement for the Assembly meeting once in six months had been fulfilled and the House need not meet till February 2005 (Yagnik and Sud 2004). This is the context in which a deeply political process of land liberalisation is being conducted in Gujarat almost by stealth. (c) As the general political context and rightward shift in the polity that have been discussed above indicate, there is a broad consensus across political formations over the liberalisation of land and the attempted 'globalisation of Gujarat' in the province. In fact, opposition of the new economic policies would be seen as

${ }^{40}$ Staff reporter, 'HC quashes land acquisition for Reliance', The Times of India, Ahmedabad Edition, 7.9.95. 
damaging Gujarat's economic prospects. Political parties thus vie with each other to express enthusiasm over land liberalisation policies. In this context, the latter have been on the increment from the mid-gos.

In November 1995, the BJP government decided to seek amendment of Section $6_{5}$ of the Bombay Land Revenue Act. This would remove existing restrictions on the conversion of agricultural land to non agricultural status for the purpose of bonafide industrial development. Now, no permission would be required from revenue officials for conversion of farm land up to 10 hectares to 'NA' (non-agricultural) status for setting up a 'bonafide industrial unit' in a specified industrial zone. It was also decreed that the area that industry could purchase from agriculturists would not be more than four times the area on which construction of an industrial unit had been proposed to come up. Calling the move 'revolutionary' the Industries Minister said this would remove the hurdles in acquiring land for industrial purposes ensuring faster development. ${ }^{41}$ Going further on the land deregulation path, the State BJP government announced a new Land Policy in February 1996. The main provision of the new policy was that henceforth, persons holding 'new tenure' (navi sharat) land for over fifteen years would be able to sell it by getting it converted into 'old tenure' (juni sharat) land for agricultural purpose. Till the latter scheme was announced, all newly allotted land in Gujarat had come under the category of 'new tenure'. This had covered land allotted to the beneficiaries of ceiling and tenancy reforms in the 1960 and 70 s, as well as beneficiaries of government wasteland development schemes. The idea of blocking 'new tenure' land from sale and purchase was that new tillers, mostly from the weaker castes and classes, might be lured into selling land for purposes like a marriage, illness, and especially to money lenders for small debts. The new tenure sale restriction was to keep the land assets of the poor secure. The principle governing this rule was land to the tiller. By 2003, this provision had been further liberalised. All 'new tenure' lands automatically became 'old tenure' from that year. Moreover, while the government may have limited permission for selling new-turned-old tenure land to agricultural purposes in its Land Policy, its previous announcement allowing the conversion of agricultural land for

${ }^{41}$ Staff Reporter, 'Curbs on conversion of farmland lifted. State to amend land revenue Act', The Times of India, Ahmedabad Edition, 2.1 2.95; Express News Service 'Land Acts to be amended to favour industry', Indian Express, Ahmedabad Edition, $4 \cdot 1 \cdot 96$. 
non-agricultural purposes meant that new tenure land was now open to sale for purposes beyond cultivation. With the announcement of the New Land Policy, the ideal of land to the tiller seems to have been officially given up in Gujarat. ${ }^{42}$

The New Land Policy has been consolidated in recent years. In January 1999, a circular from the Revenue Department (GR Jaman/3999/29/ch) of the Government of Gujarat announced the decision to sell 'gauchar' or pastoral land, which comes under village common property resources, to industrialists. The latter would be charged $3^{0}$ per cent more than the market value of the land. ${ }^{43}$ Undercutting the existing power of the Village Panchayat, the body for local self governance, to decide the fate of grazing land, the circular indicated that the decision to give away gauchar to industry could now be taken by the District Collector. There were State-wide protests to this decision by Gujarat's large Maldhari or pastoralist community. Finally, on March 11 1999, the government withdrew its gauchar-related circular. ${ }^{44}$ The official withdrawal of this scheme does not mean that pastoral lands are not being used for agricultural or industrial purposes illegally or with the district administration's permission. The 'privatisation' of gauchar or other village common property is not new to the post-9os liberalisation era. In earlier decades, common property land had been illegally privatised for cultivation, building houses or for setting up industrial units (Iyengar 2002). In this period, it had also been possible for District Collectors to give permission in specific cases to change the land use of a village pasture. After the government failed to turn the latter practice into a more all-encompassing policy in 1999, Collectors continued allowing industries, private schools, temples or social trusts to build structures on gauchars. ${ }^{45}$ In a recent development, the privatisation of gauchars has been formalised and turned into policy once again. The BJP government has re-introduced the circular allowing industry to be set up on not just village pastoral land, but all 'wasteland' in May 2005. The circular indicates the government's intention to allot 4600 ,ooo hectares of government wasteland to the corporate sector for establishing industries and to large farmers for

${ }^{42}$ Editorial, 'Endangered Peasant', Times of India, Ahmedabad Edition, 1.3.96.

${ }^{43}$ Express News Service, 'Maldharies against circular', Indian Express, Ahmedabad Edition, 22.2.99.

${ }^{44}$ Fulchab, 'Gaucharni jamin angeno paripatra pacho khenchayo', Fulchab, Rajkot, 12.3.99 (in Gujarati).

45 Interview with a District Collector, June 2004, Ahmedabad. 
technology-intensive and corporate farming. ${ }^{46} 1984$,ooo hectares of this 'wasteland' is deemed fit for cultivation. ${ }^{47}$ Like 1999 when a diluted form of this scheme was first announced, there have been some protests from Maldhari groups and from some Gandhian NGOs. ${ }^{48}$ Yet, land liberalisation has gained so much momentum in the last 10 or so years that the withdrawal of the circular announcing privatisation of pastures and 'wasteland' seems almost inconceivable. The Gujarat government has certainly not made any moves in this direction.

Liberalisation of land is still not complete, but provisions to make it so are periodically announced. For instance in 2000, the government declared a new agro-industries policy, as part of its Gujarat AgroVision 2010. In this, it suggested a 're-look at the Land Tenancy Act and the Land Ceiling Act'. Questioning the justification for agricultural land ceiling, bureaucrats indicated that with mechanised farming and large-scale industrial units being set up in Gujarat, the logic of land ceiling, set in the 6os needed to be rethought. Collectors can still allot land for industry or agro-industry over the ceiling limit. But in the climate of deregulation, the role of the Collector in granting permission to overcome ceilings was being questioned in this document. Since the Land Ceiling Act is in the concurrent list, Gujarat would have to work with New Delhi to remove this 'hurdle'. With several local, State and national elections 'coming in its way', the question of doing away with land ceilings has been put on hold. That the government is keen to go ahead with this provision is beyond doubt.

\section{Conclusion}

This paper has traced the shift in Gujarat's land policy from ideas of land to the tiller to those of land deregulation and liberalisation. It has located the shift in the State's changing political economy as well as larger changes such as the adoption of a New Economic Policy by India. In delineating the shift, care has been taken to not portray the

46 Times News Network, 'Maldharis demand pastoral zones', The Times of India, Ahmedabad Edition, 23.9.05.

47 Times News Network, 'Protest against GR on giving wasteland to industries', The Times of India, Ahmedabad Edition, 10.8.05.

${ }^{48}$ Bashir Pathan, 'Row over government's corporate farming plan', Indian Express, Ahmedabad Edition, 13.8.05. 
change in policy as a radical 180 degree turn from 'land for the poor farmer and landless labourer' ideas to those of 'land for the rich and for industry'. Despite its grounding in the rhetoric of 'land to the tiller', early land policy catered more to large middle and upper caste farmers than smaller ones. Once these groups entered the urban and semiurban sphere of agro-industry and small-scale industry, their political representatives were able to begin the process of changing land rules to facilitate easy sale and purchase. This process has gained momentum in the 1990 . But it is by no means merely a result of macro-economic change from 1991. It is also based in a local socio-economic and political context. Since my primary objective was to trace the change in policy, and since I was covering a wide chronological canvas, I have not been able to concentrate on the social groups the liberalisation of land hits. I have indicated that the overwhelming number of losers will be small farmers and landless labourers, with more and more people entering the latter category from the former. However, some upper and middle caste middle class groups are also being affected. For instance, in January 2005, massive rallies were held in Kachchh district protesting the indiscriminate award of gauchar to industry. The participants in these rallies were local pastoralists but also some members from the Gandhidham Chamber of Commerce and Industry and the Vishwa Hindu Parishad (VHP) of Kachchh! The participation of the VHP in anti land liberalisation rallies is curious, given that its own BJP government has done more to expedite land liberalisation that any other political group in Gujarat. The contradictions within the Hindu nationalist movement which show up in the messiness of its economic message is not in the ambit of this paper. That liberalisation in Gujarat is bound to be contested is quite obvious. What is also obvious, as this paper has tried to show, is the keenness of the Gujarat government, irrespective of the party in power, to continue liberalising land.

\section{References}

Adhvaryu, B. (1982) 'Land to the Landless of Hathmati', Pamphlet, Bhiloda: Shramjivi Samaj.

Alvares, C. A. and Billorey, R. (1988) Damming the Narmada: India's Greatest Planned Environmental Disaster. Penang, Malaysia: Third World Network.

Babu, H. (2003) 'The Social Engineering of Gujarat', Himal Magazine. 6 July.

Baviskar, A. (2004) In the Belly of the River: Tribal Conflicts over Development in the Narmada Valley, 2nd Edition. Delhi: Oxford University Press.

Bharatiya Kisan Sangh (2003) Bharatiya Kisan Sangh, Unpublished publicity pamphlet, Himatnagar, Gujarat (in Gujarati). 
Campaign for People's Control over Natural Resources (2000) 'The Land Acquisition, Rehabilitation and Resettlement Bill', 2000, Draft by Voluntary Organisations, Unpublished.

Corbridge, S. and Harriss, J. (2000) Reinventing India. Liberalization, Hindu Nationalism and Popular Democracy. Cambridge: Polity Press.

Directorate of Census Operations (2001) 'Provisional Population Totals: Paper II of 2001', Census of Gujarat. Ahmedabad: Directorate of Census Operations.

Frankel, F. R. (1978) India's Political Economy, 1947-1977. The Gradual Revolution. Princeton: Princeton University Press.

Government of Gujarat (1976) The Land Reforms Laws in Gujarat. Gandhinagar: Government Central Press.

Government of Gujarat (1984) Statistical Atlas of Gujarat, 2 Volumes. Gandhinagar: Government Central Press.

Government of Gujarat (2003) Gujarat Going Global. Gujarat Industrial Policy 2003. Gandhinagar: Industries and Mines Department, Government of Gujarat.

Government of India (1997) 'Poverty line for BPL Census'. Unpublished circular no. M-2801 2/16/91- IRD III, September 10. New Delhi: Ministry of Rural Areas and Employment.

Hardiman, D. (1981) Peasant Nationalists of Gujarat. Kheda District I917-1934. Delhi: Oxford University Press.

Iyengar, S. (2002) 'Common Property Land Resources in Gujarat: Some Findings about their Size, Status and Use', in Shah, G. and Sah, D. C. (Eds.) Land Reforms in India. Performances and Challenges in Gujarat and Maharashtra. Volume 8. New Delhi: Sage Publications. Pgs. 464-97.

Iyer, K. G. (2002) 'Implementation of the Land Ceiling Act in Western India', in Shah, G. and Sah, D. C. (Eds.) Land Reforms in India. Performances and Challenges in Gujarat and Maharashtra. Volume 8. New Delhi: Sage Publications. Pgs. 147-85.

Iyer, V. R. K., Sawant, P. B., Suresh, H., Kannabiran, K.G., Roy, A., Subramanian, K. S., Shah, G. and Sarkar, T. (2002) 'Crime Against Humanity. An Inquiry into the Carnage in Gujarat' Concerned Citizens Tribunal. Mumbai: Citizens for Justice and Peace.

Jadav, K. and Marvia, R. (2002) 'Krishi shetre Gujarat', in Mehta, D. (Ed.) Gujarat Etle Gujrat Ja, Ahmedabad: Vishwa Samvad Kendra (in Gujarati). Pgs. 23-28.

Jenkins, R. (1999) Democratic Politics and Economic Reform in India. Cambridge: Cambridge University press.

Kohli, A. (1990) Democracy and Discontent: India's Growing Crisis of Governability. Cambridge: Cambridge University Press.

Land Reforms Unit (1994) Land Reforms in Gujarat. An Empirical Study (I988- I99I), Mussoorie: Lal Bahadur Shastri National Academy of Administration. Volumes I and II.

Mehta, D. (Ed.) (2002) Gujarat Etle Gujrat Ja, Ahmedabad: Vishwa Samvad Kendra (in Gujarati).

Mehta, V. R. (1995) Shining Shadows. Ahmedabad: Gujarat Vidyapith.

Mooij, J. E. (1996) Food Policy and Politics. The Public Distribution System in Karnataka and Kerala, South India. Wageningen: Faculty of Politics and Social-Cultural Sciences.

Mukta, P. (2002) 'On the Political Culture of Authoritarianism', in Shah, G., Rutten, M. and Streefkerk, H. (Eds.) Development and Deprivation in Gujarat. In Honour of Jan Breman. New Delhi: Sage Publications. Pgs. 59-73.

Nandy, A., Trivedy, S., Mayaram, S. and Yagnik, A. (1995) Creating a Nationality. The Ramjanmabhumi Movement and Fear of the Self. Delhi: Oxford University Press.

Nayar, B. R. (2001) Globalization and Nationalism: The Changing Balance of India's Economic Policy, 1950-2000. New Delhi: Sage Publications. 
Parikh, R. U. (1960) 'Land Policy', Publication No. 3o. Ahmedabad: Harold Laski Institute of Political Science.

Rothermund, D. (1996) Liberalising India: Progress and Problems. New Delhi: Manohar.

Rutten, M. (1991) Capitalist Entrepreneurs and Economic Diversification: Social Profile of Large Farmers and Rural Industrialists in Central Gujarat, India, Unpublished PhD Thesis: University of Amsterdam.

Shah, G. (2002) 'Caste and Land Reforms in Gujarat', in Shah, G. and Sah, D. C. (Eds.) Land Reforms in India. Performances and Challenges in Gujarat and Maharashtra. Volume 8. New Delhi: Sage Publications. Pgs. 127-43.

Shah, G. and Sah, D. C. (2002) 'Editors' Introduction', in Shah, G. and Sah, D. G. (Eds.) Land Reforms in India. Performances and Challenges in Gujarat and Maharashtra. Volume 8. New Delhi: Sage Publications. Pgs. 19-35.

Shani, O. (2001) The Making of Ethno Hinduism in India: Communalism, Reservations and the Ahmedabad Riots of $19^{8} 5$. Cambridge: Unpublished PhD Thesis.

Soyantar, T. D. (1994) 'Law and Landlessness in Gujarat. An Overview', Unpublished paper.

Vijapurkar, M. (1993) 'Pawar kicks up a new row', The Hindu, Delhi Edition, 20/7/93. Vyas, B., Parmar, R., Parmar, K., Chaudhary, A., Jani, M., Khatsuriya, H., Mahida, C. and Yagnik, A. (1989) 'Gujarat Sarkarni Garib-Virodhi Chaal Jamin Kaydama 'Chutchat' niJaherat', Pamphlet, Ahmedabad: Gujarat Vishamta Nirmulan Parishad (in Gujarati).

Wood,J. R. (1975) 'Extra-Parliamentary Opposition in India: An Analysis of Populist Agitations in Gujarat and Bihar', Pacific Affairs, Vol. 48, Number 3, Pgs. 313-34.

Yagnik, A. (2002) 'The Pathology of Gujarat', Seminar No. 513. May. Pgs. 19-22.

Yagnik, A. and Sud, N. (2004) 'Hindutva and beyond: the political topography of Gujarat', Paper presented at the Conference on State politics in India in the 1990's: political mobilisation and political competition, India International Centre, New Delhi, December 16-17.

\section{Newspapers}

Fulchab (in Gujarati)

Gujarat Samachar (in Gujarati)

Hindustan Times, Delhi Edition

Indian Express, Ahmedabad Edition

Sandesh (in Gujarati)

The Asian Age, Ahmedabad Edition

The Hindu, Delhi Edition

The Times of India, Ahmedabad Edition 
